DOI: https://doi.org/10.24867/13GI07Popovic

\title{
POVEZANOST TIMSKIH ULOGA I STILOVA LIDERSTVA U PROIZVODNOJ ORGANIZACIJI
}

\section{RELATIONSHIP BETWEEN TEAM ROLES AND LEADERSHIP STYLES IN PRODUCTION ORGANISATION}

\author{
Jelena Popović, Fakultet tehničkih nauka, Novi Sad
}

\begin{abstract}
Oblast - MENADŽMENT LJUDSKIH RESURSA
Kratak sadržaj - Rad se bavi analizom i utvrđivanjem prirode povezanosti timskih uloga $i$ stilova liderstva. Obuhvaćeni su zaposleni jedne proizvodne organizacije, rukovodećih $i$ nerukovodećih poziicja. Uz pomoć dva upitnika i statističkog programa analizirana je sklonost timskih uloga određenom stilu liderstva.
\end{abstract}

Ključne reči: Tim, timski rad,timske uloge, liderstvo, stilovi liderstva

Abstract - The paper deals with the analysis and determination of the nature of the connection between team roles and leadership styles. Employees of one production organization, managerial and non-managerial positions are included. With the help of two questionnaires and a statistical program, the propensity of team roles for a certain leadership style was analyzed

Keywords: Team, teamwork, team roles, leadership, leadership styles.

\section{UVOD}

Pojave koje se u poslednje vreme proučavaju jesu timske uloge, ali i liderstvo. Za odlično poslovanje jedne organizacije bitno je da svako ima definisanu i jasnu timsku ulogu, dok je liderstvo fenomen koji je neophodan kako bi se ljudi različitih uloga vodili ka pravom cilju.

Dobar timski rad može da se postigne prvo jasnim razgraničenjem i razumevanjem timskih uloga, a na osnovu toga i formiranjem pravog tima.

Kako bi lideri kreirali najbolji mogući tim, najčešće se oslanjaju na Belbinov model timskih uloga. Meredith Belbin je definisao timsku ulogu kao ,tendenciju ponašanja, doprinošenja i povezanosti sa drugima na određen, specifičan način“ i imenovao devet uloga u timu koji su osnova timskog uspeha. Belbin predlaže da, razumevanjem uloge u određenom timu, članovi mogu da razviju svoje snage i upravljaju svojim slabostima i tako poboljšaju kvalitet rada. [1].

Kvalitetno liderstvo podstiče poverenje, posvećenost i lojalnost sledbenika. Lider je odličan mentor, harizmatičan i inspirativan, pomaže svojim saradnicima da se izbore sa stresom i kriznim situacijama. Takođe, lider ima jasnu viziju i sa svojim saradnicima teži da je ostvari.

\section{NAPOMENA}

Ovaj rad proistekao je iz master rada čiji mentor je bila dr Leposava Grubić Nešić, red. prof.

\section{ZNAČAJ MODELA TIMSKIH ULOGA}

Različite su koristi koje donosi Belbinov model timskih uloga. Prvo i najvažnije, kvalitetno postavljene uloge doprinose kreiranju dobrog tima.

Takođe, veliku korist od ovog modela imaju i menadžeri. Uvidom $\mathrm{u}$ rezultate testa mogu videti ključne snage $\mathrm{i}$ slabosti svih članova i iskoristiti ih na najbolji mogući način. Menadžeri se mogu poboljšati i od menadžera za procese postati bolji menadžeri za ljude.

Timske uloge pružaju detaljan uvid u ličnost pojedinca, ali i u celokupan tim. Obzirom da timovi među sobom mogu biti takmičarski nastrojeni, to može dovesti do frustracija i konflikata. Razumevanjem timskih uloga mogu se eliminisati kompetitivnost i nametljivost, te se takmičarske tendencije mogu okrenuti $u$ korist organizacije [2].

Jasnim utvrđivanjem timskih uloga smanjiće se svađe i nesporazumi između članova. Neće postojati zabuna oko toga ko će se pobrinuti za različite zadatke i aspekte projekta i pojava nerazumevanja odgovornosti u startu ne nastaje. Ovo poboljšava odnose između članova i minimizira odvlačenje pažnje. Takođe, može se umanjiti ili čak potpuno eliminisati suvišnost.

Najvažnije, kada je tim pravilno formiran, svakom članu su jasni njegovi zadaci, odgovornosti i zaduženja. Zbog toga nema nejasnoća i gubljenja vremena kada je u pitanju obavljanje poslova.

Timske uloge su takođe značajne jer smanjuju nezdravu konkurenciju, članovi nemaju tendenciju da se bore oko različitih poslova, svako ima svoja zaduženja i formiraju se pozitivni odnosi i kvalitetnija komunikacija. [3].

\subsection{Tipovi timskih uloga}

Meredith Belbin je definisao devet različitih tipova ljudi koji se mogu naći u timu. Podelio ih je u tri različite grupe: uloge orjentisane prema aktivnostima, uloge orjentisane prema ljudima i uloge orjentisane prema veštinama. Svaka uloga tima povezana je sa tipičnim ponašanjima, snagama i slabostima. Uloge orjentinisane ka aktivnostima su: modelator, finišer i snalažljivi organizator. Modelator je je dinamičan, ekstrovertan, $u$ svemu vidi izazov, dok je finišer perfekcionista koji sve poslove obavlja na vreme, pazi na rokove i potencijalne greške. Snalažljivi organizator je efikasan i praktičan, pouzdan, ideje pretvara u akcije.:

Uloge orjentisane prema ljudima su: timski radnik, istraživač i koordinator. Timski radnik u fokus stavlja 
koheziju tima, orjentisan je ka ljudima i diplomata, istraživač je komunikativan, ekstrovertan i timu uvek pruža nove kontakte. Koordinator se karakteriše kao „vođa“, dobro delegira zadatke, efikasan je i brz.

Uloge orjentisane ka veštinama su: evaluator, specijalista i inovator. Evaluator ili sudija misli hladne glave, dobro procenjuje i sagledava sve iz različitih uglova. Specijalista ima odlične veštine i sposobnosti, stručnjak je u određenoj oblasti, dok inovator predstavlja originalnog mislioca koji je maštovit, inovativan i razmišlja izvan okvira.

\section{STILOVI LIDERSTVA}

Prema velikom broju autora lideri se mogu podeliti na: autoritarne (lideri koji podređenima naređuju šta trebaju da urade); transformacione (lideri koji inspirišu i motivišu svoje sledbenike) i harizmatične (lideri koji imaju visoko samopouzdanje, pružaju podršku drugima, dominantni su i energični). [4].

Lideri mogu biti orjentisani na strukturu, ljudske resurse, na politiku ili mogu biti vizionarski orjentisani.

Ipak, još češća podela stilova liderstva jeste i ona koja je korišćena za svrhe ovog istraživanja jeste podela na: autokratski stil (strog, hijerarhijski stil, gde sledbenici ne učestvuju u procesu donošenja odluka ), demokratski stil (zasnovan na znanju i veštinama, gde svi učestvuju u odlučivanju i postoje čvrste veze između lidera i sledbenika) i nelidersko ponašanje ili liberalni stil (gde lider većinu stvari prepušta svojim sledbenicima $\mathrm{i}$ oni imaju visok stepen nezavisnosti. Lider $u$ ovom stilu koristi svoju moć na minimalnom nivou)

\subsection{Povezanost personalnih karakteristika $\mathbf{i}$ liderstva}

Lideri su otvoreni, ekstrovertni i društveni. Može se očekivati da su puni samopouzdanja i imaju visoko samopoštovanje. Takođe se očekuje da su transformacioni lideri pozitivni, optimistični i emocionalno uravnoteženi, da su sposobni da se nose sa stresnim situacijama i složenim okruženjima. Konačno, osobe koje vode druge ljude trebalo bi da su inovatori i verovatnije je da će preuzimati rizike više nego netransformacioni lideri.

Neke od osobina koje se mogu dovesti u vezu sa kvalitetnim liderstvom jesu: ekstrovertnost, samopouzdanje, lokus kontrole. Ekstrovertne osobe, odnosno one koje su društvene, pričljive i vole društvo verovatnije su da budu kvalitetniji lideri od onih koji su introvertni i zatvoreni.

Dominantnost, tendencija da se preuzme odgovornost $\mathrm{u}$ kriznim situacijama dovedena je u vezu sa efikasnim liderstvom. Efikasni lideri uglavnom imaju visok nivo samopouzdanja i samopoštovanja. Dobar lider preuzima rizik i odgovornost za svoje postupke, ima unutrašnji lokus kontrole što znači da veruje da on sam ima ličnu kontrolu nad sopstvenim životom.

Pored kognitivne inteligencije, sa kvalitetnim liderom se povezuje i posedovanje emocionalne inteligencije, (sposobnost prepoznavanja kako sopstvenih, tako i osećanja drugih ljudi) kao i socijalne (mudro postupanje u socijalnim situacijama, razumevanje ljudi i sposobnost razmišljanja i rešavanja problema).

\section{ISTRAŽIVANJE}

Istraživanjem $u$ ovom radu se ispitivala veza između timskih uloga i stila liderstva, odnosno utvrđivalo se da li timska uloga koju pojedinac ima zaista utiče na njegov stil liderstva. Prilikom istraživanja u obzir su uzeti zaposleni različitog pola, uzrasta, kao i pozicije $u$ organizaciji. $\mathrm{Uz}$ navedene demografske varijable, korišćena su dva upitnika - Belbinov test timskih uloga $\mathrm{i}$ upitnik stilova liderstva.

Belbinov test timskih uloga se sastoji od 7 oblasti od kojih svaka ima po 8 izjava. Ispitanicima je na raspolaganju ukupno 10 bodova koje mogu raspodeliti na tih 8 tvrdnji. Raspodela se može izvršiti na različite načine, ispitanik može da dodeli 10 bodova samo jednoj rečenici sa kojom je najviše saglasan i koja najbolje opisuje njegovo ponašanje, ili može da raspodeljuje manji broj bodova $(1,2,3 \ldots)$ na različite izjave dok ne zbir ne bude 10. Upitnik stilova liderstva se sastoji od 18 pitanja na koje ispitanici odgovaraju kroz Likertovu skalu, odnosno izražavaju stepen svog slaganja ili neslaganja sa navedenim pitanjima. Ukupni zbirovi pojedinih pitanja daju odgovor da li pojedinac ispoljava autokratski, demokratski stil liderstva ili nelidersko ponašanje.

\subsection{Metod istraživanja}

Uzorak istraživanja čini 58 zaposlenih u proizvodnom preduzeću „Insert“ d.o.o. Zaposlenima su upitnici dostavljeni fizičkim putem, a iste su popunjavali na radnom mestu. Objašnjena im je procedura popunjavanja upitnika i anonimnost je zagarantovana.

U istraživanju je učestvovalo ukupno 58 zaposlenih - 26 učesnika muškog pola ( $44.8 \%$ ) i 32 učesnika ženskog pola $(55.2 \%)$.

Analizom frekvencije u programu SPSS utvrđeno je da je $\mathrm{u}$ istraživanju učestvovalo 7 učesnika uzrasta manje od

25 godina (12.1\%), 12 učesnika uzrasta 26-30 godina (20.7\%), 13 učesnika uzrasta 31-40 godina (22.4\%), 14 učesnika uzrasta 41-50 godina (24.1\%) i 12 učesnika koji imaju preko 50 godina $(20.7 \%)$.

Istraživanje je obuhvatilo 15 osoba (25.9\%) koje su na rukovodećoj radnoj poziciji i 43 osobe koje su na nerukovodećem radnom mestu (74.1\%).

\subsection{Merni instrumenti $u$ istraživanju}

Merne instrumente u ovom istraživanju čine dva upitnika. Prvi je Belbinov test timskih uloga. Kao što je već napomenuto, ovaj test se sastoji iz 7 oblasti, svaka od njih sadrži 8 izjava. Zadatak ispitanika je da ukupno 10 bodova rasporede na ovih 8 izjava (bodovi se dodeljuju $\mathrm{u}$ zavisnosti od toga u kojoj meri je ispitanik saglasan sa napisanom tvrdnjom). Prenošenjem dodeljenih poena $u$ određene kolone koje odgovaraju timskim ulogama dobijaju se rezultati.

Drugi merni instrument je upitnik stilova liderstva. Upitnik se sastoji od 18 izjava, a ispitanik treba da zaokruži u kojoj je meri saglasan sa datim tvrdnjama ( $1=$ uopšte se ne slažem; $2=$ ne slažem se; $3=$ neutralan/na; 4= slažem se; $5=$ u potpunosti se slažem).

U zavisnosti od zbira koji se dobije iz određenih pitanja, rezultat može biti autokratski, demokratski stil liderstva ili 
nelidersko ponašanje, odnosno liberalni stil. Izjave broj 1,4,7,10,13 i 16 ukazuju na autoritarni stil liderstva, izjave broj 2,5,8,11,14 i 17 ukazuju na demokratski stil, dok pitanja 3,6,9,12,15 i 18 ukazuju na nelidersko ponašanje

\subsection{Postupak i obrada podataka}

Istraživanje je sprovedeno tokom meseca septembra 2020.godine u proizvodnoj organizaciji „Insert“ d.o.o i obuhvatilo je ukupno 58 zaposlenih, od kojih je muškog pola bilo njih 26, a ženskog pola 32. Zaposleni su popunjavali upitnike na svom radnom mestu uz dobijenu saglasnost rukovodioca. Objašnjena im je svrha istraživanja i zagarantovana anonimnost

Dobijeni podaci su obrađeni u statističkom programu SPSS. Nakon unošenja svih odgovora u program, urađene su sledeće analize - analiza pouzdanosti (Kronbahov alfa koeficijent), deskriptivna statistika, analiza frekvencije, aritmetičke sredine i standardne devijacije, analiza korelacije ( $\mathrm{p}$ vrednost), $\mathrm{x}^{2}$ test, $\mathrm{i}$ na kraju najvažnija analiza varijansi (ANOVA). Rezultati prikazuju razliku ispitanika u različitim demografskim strukturama - pol, broj godina i pozicija u organizaciji.

\section{REZULTATI ISTRAŽIVANJA}

Ono što je prethodilo analizama u program u SPSS jeste deskriptivna statistika i analiza frekvencije koja prikazuje tačnu razliku u odgovorima ispitanika. Uvidom $\mathrm{u}$ analizu frekvencije jasno je koliko je tačno učesnika muškog, odnosno ženskog pola, koliko njih je na rukovodećoj, odnosno nerukovodećoj poziciji i na kraju, kog su uzrasta ispitanici.

Kako bi se utvrdila povezanost između timskih uloga i stilova liderstva, urađena je analiza korelacije tj. povezanosti. Statistička značajnost se u istraživačkim radovima često naziva p-vrednost (skraćeno od ,vrednost verovatnoće“). Nivo statističke značajnosti - p vrednosti izražava se vrednošću između 0 i 1 . Što je manja pvrednost, to su jači dokazi da bismo trebali odbiti nultu hipotezu, odnosno da ne postoji značajna veza između dve varijable koje posmatramo. Kada je vrednost p manja od 0,05 (ili $\leq 0,05$ ), to implicira da je veza statistički značajna, što je i prikazano na narednoj slici (slika 1.)

\section{Correlation}

\begin{tabular}{|c|c|c|c|}
\hline & & $\begin{array}{c}\text { Timske_ulog } \\
\text { e_rezultat }\end{array}$ & $\begin{array}{c}\text { Stil_liderstva } \\
\text { rezultat }\end{array}$ \\
\hline \multirow[t]{3}{*}{ Timske_uloge_rezultat } & Pearson Correlation & 1 & $259^{\prime \prime}$ \\
\hline & Sig. (2-tailed) & & 049 \\
\hline & $\mathrm{N}$ & 58 & 58 \\
\hline \multirow[t]{3}{*}{ Stil_liderstva_rezultat } & Pearson Correlation & $259^{*}$ & 1 \\
\hline & Sig. (2-tailed) & .049 & \\
\hline & $\mathrm{N}$ & 58 & 58 \\
\hline
\end{tabular}

Slika 1. Rezultat istraživanja

Nulta hipoteza u ovom istraživačkom radu bi glasila da ne postoji značajna veza između dve posmatrane varijable timske uloge i stilovi liderstva. Međutim, pošto je p vrednost $0.049 \approx 0.05$, može se reći da se nulta hipoteza odbija, odnosno - postoji značajna korelacija između timskih uloga i stilova liderstva. Dakle, statistički je značajna veza između dve posmatrane varijable $u$ istraživanju.
Potvrđena je hipoteza da timske uloge utiču na stil liderstva. Međutim, pol, uzrast ispitanika i njihova pozicija u organizaciji ne utiču značajno na stil liderstva. Istraživanje je takođe pokazalo da je najviše ispitanika saglasno sa izjavama koje odgovaraju baš ovom stilu liderstva, a većina njih bile su žene. Ispitanici muškog pola pokazali su sklonost ka autokratskom stilu liderstva, a takođe su prednjačili i $\mathrm{u}$ ispoljavanju neliderskog ponašanja, odnosno liberalnom stilu vođenja.

\section{POVEZANOST TIMSKIH ULOGA I LIDERSTVA}

Autokratski stil ispoljili su modelatori, finišeri, koordinatori i specijalisti; demokratskom stilu su skloni snalažljivi organizatori, timski radnici i evaluatori, dok u liberalnom stilu prednjače istraživači i inovatori. Kao potencijalne mane modelatora $i$ finišera ističu se manipulacija, provokacija i loše delegiranje zadataka, koordinator takođe može da se doima kao manipulator jer izvršava zadatake te je i razumljivo da su oni pokazali strogi, autokratski stil liderstva. Ovaj stil karakteriše se krutim, nefleksibilnim ponašanjem uz vrlo malo prilagođavanja drugim ljudima.

Osobe koje su se najviše usaglasile sa izjavama koje opisuju demokratski stil liderstva su snalažljivi organizator, timski radnik i evaluator. Ove osobe smatraju da svi treba da učestvuju u donošenju odluka i da je komunikacija najbitnija u timu. Dobar rad i kvalitetni rezultati zasnivaju se na konstantnoj saradnji lidera i njegovih sledbenika. Timski radnik, kao što mu i samo ime kaže, na prvo mesto stavlja koheziju tima , orjentisan je ka ljudima i dobroj komunikaciji, evaluator razmišlja hladne glave i uzima u obzir mišljenje svih učesnika, dok je snalažljivi organizator svestran i preduzimljiv. Baš zbog ovih kvaliteta je jasno zašto ove uloge pokazuju sklonost ka demokratiji

Nelidersko ponašanje, odnosno liberalni stil vođenja podudara se sa istraživačem i inovatorom $u$ timu. Istraživač lako izgubi fokus, teško zadržava pažnju i gubi početno interesovanje vrlo brzo. Inovator je često introvertan, loše komunicira i ignoriše probleme te je jasno da pokazuje sklonost ka neliderskom ponašanju. Ovakav stil liderstva karakteriše slaba veza između sledbenika i lidera i činjenica da lider olako prepušta donošenje odluka drugim ljudima, te zbog toga ne želi da snosi odgovornost.

\subsection{Razlike između ispitanika na dimenzijama stila liderstva u odnosu na pol}

Tabela 2. prikazuje da su žene najviše okrenute demokratskom stilu liderstva, a muškarci autokratskom.

Tabela 2. Razlike liderskog stila u odnosu na pol ispitanika

\begin{tabular}{|c|c|c|}
\hline Stil liderstva & Muški pol & Ženski pol \\
\hline Autokratski stil & 11 & 9 \\
\hline Demokratski stil & 5 & 18 \\
\hline Liberalni stil & 9 & 6 \\
\hline
\end{tabular}




\section{PREDLOG MERA POBOLJŠANJA SA ASPEKTA TIMSKOG RADA}

Ključ svakog uspešnog timskog rada jeste dobra komunikacija. Efektivni timovi često komuniciraju, članovi između sebe dele ideje i predloge, zajednički traže rešenja problema. Dakle, timu je potrebna efikasna komunikacija, bila ona preko e - maila, drugih komunikacionih alata ili uživo. Sastanci su naravno najbolja opcija, gde članovi tima mogu jedni druge da slušaju pažljivo i sa empatijom, umesto da samo „čekaju svoj red“ da bi izneli problem.

Sledeće što ljudi u timu mogu da urade jeste da, ma koliko su različiti u svojim ulogama, potraže svrhu celokupnog rada. Bilo da je to neki projekat, finalni izveštaji, ili u ovom slučaju čitav proces proizvodnje, ukoliko tim ne zna šta radi i zašto to radi - gubi se motivacija, entuzijazam i usmerenost na cilj.

Obzirom da je ovo istraživanje dalo rezultate koji nam govore da su u organizaciji prisutne sve timske uloge, potrebno je fokusirati se na njihove snage i kvalitete. Svaka timska uloga ima mnogo prednosti, a samim tim i zaposleni koji pripada određenom tipu uloge može mnogo da doprinese. Ljudi su različiti - svi imamo različite snage, strasti i slabosti.

Osnova dobrog vođenja tima je fokusiranje na snage pojedinaca i okupljanje tima ljudi koji imaju kombinovani skup veština da bi posao obavili na pravi način. Dok god svi doprinose donoseći znanja i

veštine u tim, ne treba se mnogo zadržavati na njihovim slabostima. Naravno, slabosti se ne ignorišu i treba ih

otklanjati, ali pravi fokus mora biti na pozitivnim stvarima koji svaki pojedinac može dati timu.

Različiti tipovi ličnosti objašnjeni u ovom radu imaju i različita mišljenja, što ponekad dovodi do neslaganja, frustracija ili konflikata. Svako neslaganje ili razlika u mišljenjima je prilika da se nauči nešto novo i da se upoznaju razni šabloni ponašanja drugih ljudi. Sa ljudima koji imaju suprotno mišljenje treba postupiti sa uvažavanjem, pažnjom i poštovanjem. Iz varijacija mišljenja uvek se može izroditi nova ideja.

\section{ZAKLJUČAK}

U suštini, ne postoje dobre ili loše timske uloge. Bitno je na najbolji mogući način kreirati kohezivan i produktivan tim sagledavanjem doprinosa koji svaki član može dati kroz svoje kvalitete. Suština timskog rada jeste dobra komunikacija kako bi članovi verovali jedni drugima, stekli osećaj zajedništva i prihvaćenosti.

Za timski rad najvažnija je upravo različitost koju svaki član unosi sa sobom. Dokazano je da svaki član tima može imati drugačije viđenje o stilu liderstva koji je najbolji i u tome je upravo srž kreiranja tima sa članovima raznolikih stavova, mišljenja i kvaliteta.

58 ispitanika ovog istraživanja ima različitu viziju o najpogodnijem stilu liderstva. Koji god od tri stila liderstva se nekom činio najprikladnijim, istina je da lider tima uvek mora postaviti prioritete i pratiti ih. Prava vizija i vođenje tima ka jasno zacrtanom cilju zadatak je svakog lidera.

\section{LITERATURA}

[1] https://www.belbin.com/about/belbin-team-roles/ (pristupljeno u septembru 2020.)

[2] https://www.belbin.com/about/why-use-belbin/ (pristupljeno u septembru 2020.)

[3] https://go.projectriskleader.com/clearly-defined-rolesare-more-important-to-teamwork-than-clearlydefined-work (pristupljeno u septembru 2020)

[4] Grubić Nešić, Leposava, „Znati biti lider“, Fakultet tehničkih nauka, pp. 74 - 84, Novi Sad, 2013.

\section{Kratka biografija:}

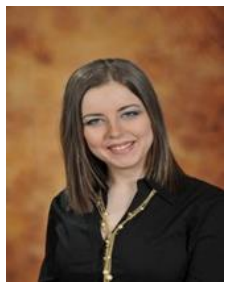

Jelena Popović rođena je u Sremskoj Mitrovici 1995. godine. Diplomski rad na Fakultetu tehničkih nauka iz oblasti Inženjerski mendžment - Stres i greške na radu u proizvodnoj organizaciji odbranila je 2019. godine.

Kontakt: popovicjelena1995@gmail.com 